\title{
A hAZAI TANÜGYIGAZGATÁS JOGSZABÁLYI KERETEI
}

\author{
RÓNAY ZOLTÁN
}

ELTE Pedagógiai és Pszichológiai Kar, Neveléstudományi Intézet

A tanügyigazgatás fogalmának nincs egységesen elfogadott, „kötelező” tudományos meghatározása, és a kodifikátor sem vállalkozott értelmező rendelkezés megalkotására. Mindez kiemeli a jogszabályi keretek szerepét, mert a normatív rendelkezések alapján egyrészt rekonstruálható a jogalkotói szándék, másrészt azok adnak segítséget a tevékenységet végzők számára nem csupán jogaik és kötelezettségeik tekintetében, hanem arról is, egyáltalán tanügyigazgatás-e, amit folytatnak. A tanulmány megkísérli megkonstruálni a fogalmat, ehhez pedig áttekinti azok egyes elemeit a kormányzati tevékenységtől egészen az intézmény szintjéig, egyfajta horizontális és vertikális bemutatásra vállalkozva. Ugyanakkor az is megállapíthatóvá vált, hogy a tanügyigazgatás jogi meghatározatlansága lehetőséget ad az államnak közvetlen beavatkozásra a tanügyigazgatás valamennyi szintjén.

Kulcsszavakः ágazatirányítás, fenntartói irányítás, Klebelsberg Központ, tankerület, intézményvezetés, munkáltatói jogok

There is a lack of consistent and accepted compulsory definition of educational administration in the Hungarian science and the special provisions among the Hungarian legal norms. Therefore, the role of legal frameworks is more important. Firstly, the legislative intent can be reconstruction on the ground of the legal norms; secondly, they can help for them are working in the administration, to know their rights and obligatory; and if their activity is educational administration. The study tries to construct the term of educational administration and surveys the components of it from the level of government down to the schools, offering a horizontal and vertical presentation of this process. Furthermore, it was recognised that the educational administration without clear legislative definition makes possible a direct influence of state on all level of educational administration.

Keywords‡ sector-control, maintainer’s control, Klebelsberg Centre, educational district, institutional management, employer's rights

Levelező szerző: Rónay Zoltán, ELTE Pedagógiai és Pszichológiai Kar, 1075 Budapest,

Kazinczy u. 23-27. E-mail: ronay.zoltan@ppk.elte.hu 


\section{Bevezető}

$\mathrm{A}$ mikor megkaptam a felkérést arra, hogy a tanügyigazgatás jogi kereteit bemutassam, az első gondolatom az volt, vajon közmegegyezés van-e abban, hogy mit is értünk tanügyigazgatás alatt. A tanügyigazgatás az a fogalom, amelyet ismerünk és használunk, s vélhetően sokan nagyjából ugyanazt értjük alatta, de korántsem biztos, hogy mindez egy általánosan elfogadott egységes definíción alapul. Azonban azzal szembesültünk, hogy a fogalom meglehetősen képlékeny, amely mellett az igazgatás állam- és intézményrendszer-szervező szerepe is megnöveli a jogi meghatározottság fontosságát, ezért megalapozott lehet a várakozásunk, hogy a jogalkotó a keretek kialakítása során magát a fogalmat is meghatározta, legalábbis jogi-igazgatási szempontból. Amint azt látni fogjuk, e téren (is) csalódnunk kellett. Mindazonáltal a kodifikált definíció hiánya még inkább hangsúlyossá teszi a jogi szabályozás szerepét. A tanügyigazgatásban tevékenykedő vagy azzal kapcsolatba kerülő személy számára ugyanis a jogszabályoknak kellene eligazítást adni - meghatározva jogaikat és kötelezettségeiket, világos és átlátható kereteket adva tevékenységüknek, kijelölve mozgásterüket. Annál is inkább, mert a fogalmi tisztázatlanság következtében valószínűsíthető, hogy nem is minden esetben van tisztában a cselekvő egyén azzal, hogy tanügyigazgatási vagy ahhoz kapcsolódó tevékenységet valósít-e meg.

Mindezekre tekintettel a jelen tanulmányban megkíséreljük a tanügyigazgatás-fogalom meghatározását a jogszabályok elemzése ${ }^{1}$ és a hazai szakirodalomban megjelenő közvetlen vagy közvetett interpretációk alapján. Ehhez az áttekintett és elemzett jogszabályokat felhasználva bemutatjuk a tanügyigazgatás főbb fogalmi elemeit (horizontális áttekintés) és annak különféle szinteken történő megvalósulását a kormányzati hatásköröktől kiindulva egészen az intézményi szintig (vertikális áttekintés). Ebben a megközelítésben az is egyértelművé válik, hogy a jogi keretek felvázolása nem csupán egy adalék a tanügyigazgatás problematikájának tudományos fejtegetéséhez, hanem kiemelt aktualitással bír közel nyolc évvel a legutóbbi tanügyigazgatást is érintő, átfogó reform kezdete után, amelynek egyik sajátossága annak részbeni lezáratlansága a már megvalósult korrekciók és folyamatosan jelzett és elvárt felülvizsgálat és revízió iránti igény következtében.

\section{A tanügyigazgatás fogalma}

Amint az előbb már említettük, a tanügyigazgatásnak nincs egyértelmű jogszabályi definíciója, sőt az egyes jogszabályok abban sem következetesek, hogy egybe vagy kötőjellel írják-e a fogalmat. A Nemzeti Jogszabálytárban elvégzett tárgyszavas keresés mindöszsze tizenkilenc releváns találatot eredményez a tanügyigazgatásra, s a „tanügy” szóra keresve is csupán negyvenhéttel több találatot kapunk, ráadásul ezek egyike sem definitív jellegü rendelkezést tartalmazó jogszabály vagy közjogi szervezetszabályozó eszköz.

1 A tanulmányban feldolgozott jogszabályelemzésre a Nemzeti Kutatási Fejlesztési és Innovációs Alapból biztosított támogatással, a K_18 pályázati program finanszírozásában megvalósuló „A pedagógusok folyamatos szakmai fejlődési modelljeinek vizsgálata a köznevelési rendszer, a szervezet és az egyén szintjén” címü 128738 számú projekt keretében került sor. 
Jelentős részben költségvetéssel összefüggő vagy más technikai rendelkezést tartalmazó jogszabályról van szó. A közneveléshez vagy távolabbról az iskolaügyhöz kapcsolódó jogszabályok, ha említik is a tanügyigazgatást, maguk is különösebb értelmezést nem igénylő fogalomként használják azt. Néhány példa a teljesség igénye nélkül: A Kormány tagjainak feladat- és hatásköréről szóló 94/2018. (V. 22.) Korm. rendelet is csak egyszer utal rá, de meglepő módon nem az oktatásért felelős miniszter hatáskörét megállapító rendelkezések között, hanem az innovációért és technológiáért felelős miniszter építésgazdaságért való felelőssége keretében ellátandó, az építésüggyel összefüggő oktatási, továbbképzési és tanügyigazgatási feladatokat rögzítve [124. § (2) bek.]. A pedagógusképzéssel és -továbbképzéssel kapcsolatos különböző jogszabályok is csak mint az elsajátítandó és fejlesztendő ismeretek egyikét említik a tanügyigazgatást, s a pedagógiai szakmai szolgáltatások között is mint ellátandó tevékenység kerül felsorolásra részletesebb tartalmi magyarázat nélkül. Különösen meglepő, hogy az emberi erőforrások miniszterének az Emberi Erőforrások Minisztériuma (EMMI), az Oktatási Hivatal $(\mathrm{OH})$ és a Klebelsberg Központ $(\mathrm{KK})$ szervezeti és müködési szabályzatát ${ }^{2}$ megállapító utasításai sem egységesek abban, hogy miként és milyen részletezettséggel tüntetik fel a fogalmat. Az első esetben csak a szervezeti egységek nevében (EMMI Tanügyigazgatási Osztály) fordul elő, a KK esetében még ily módon sem. Az OH-ra vonatkozó utasítás az egyetlen, amely megállapítja a Tanügy-igazgatási és Köznevelési Hatósági Főosztály hatáskörét, amelyből már következtethetünk a fogalom tartalmára. Ezzel áll valamelyest összhangban a Nemzeti Szakképzési és Felnőttképzési Hivatal Szervezeti és Müködési Szabályzatáról szóló 16/2017. (V. 24.) NGM-utasítás, amely az Intézményirányítási Főosztály tanügyigazgatási feladatait sorolja fel.

Mindezekből arra következtethetünk, hogy - legalábbis két esetben - a jogalkotó a tanügyigazgatás körébe sorolta egyebek mellett a szakmai koordinációt, az intézményi dokumentumok előkészítésének támogatását és azok jóváhagyását, a beiskolázási, tanévlebonyolítási, szervezési, feladatellátási ügyek támogatását, irányítását, felügyeletét és ellenőrzését, valamint általános ellenőrzési és felügyeleti jogkörök gyakorlását hivatalból és kérelemre (panasz alapján), különböző egyedi és általános engedélyezési jogköröket, szakmai és módszertani tanácsadást, irányelvek kiadását, elemzések, tervek készítését. Az $\mathrm{OH}$ esetében ezek a típusú hatáskörök mint az említett fóosztály tanügyigazgatási és szakmai ellenőrzési feladatai jelennek meg, azonban maga a szervezeti egység ellát egyebek mellett pedagógusminősítéssel, pedagógiai-szakmai ellenőrzéssel (tanfelügyelet), köznevelési akkreditációval, tankönyvvé nyilvánítással, tankönyvjegyzékkel kapcsolatos feladatokat is, ezáltal pedig a tanügyigazgatás spektruma is kitárul, szembesítve minket a fogalom „végtelen összetettségével” (Váradi 2009: 113).

A fenti felsorolásból az is jól látszik, hogy a tanügyigazgatási tevékenységnek egy szükebb és egy tágabb értelemben vett értelmezése is jelen van. Előbbi a szigorú értelemben vett közigazgatási cselekmények (igazgatás, nyilvántartás és regisztráció, ellenőrzés, tájékoztatás és kapcsolódó vagy kiegészítő szolgáltatások) megvalósítását (vö. Fazekas 2017) jelenti, utóbbiak azonban ennél szélesebb perspektívájú szakpolitikai és

2 Lásd az alábbi közjogi szervezetszabályozó eszközöket: Emberi Erőforrások Minisztériuma Szervezeti és Müködési Szabályzatáról szóló 16/2018. (VII. 26.) EMMI utasítás; az Oktatási Hivatal Szervezeti és Működési Szabályzatáról szóló 60/2015. (XII. 29.) EMMI utasítás; a Klebelsberg Központ Szervezeti és Müködési Szabályzatáról szóló 61/2016. (XII. 29.) EMMI utasítás. 
szakmai feladatokra, valamint akár az egyedi intézmény napi szintű müködését érintő (pl. munkáltatói jogkörrel összefüggő) tevékenységre is kiterjednek. Ennek megfelelően a tanügyigazgatás - jogi értelemben - felöleli a kormányzat által a köznevelés rendszerszintű működtetésétől az intézmények müködtetésén át azok napi jellegü vezetéséig tartó hatásköröket, amelyeket másképpen ágazatirányításnak, fenntartói irányításnak (vö. Csapó 1998) és intézményvezetésnek hívunk - mely fogalmakat és azok szabályozásban való megjelenését a következő részben tárgyaljuk. Míg az első két esetben a szervezeten kívül megvalósuló, a szervezetre kívülről érkező kötelezésről van szó, az a harmadik esetben már a szervezeten belül valósul meg (Bosánszky 1986). Az irányítás is a vezetés alapvető jegyeit hordozza, azaz az utasítást, koordinációt és ellenőrzést (Fayol 1920). A hazai tanügyigazgatás sajátossága, hogy ezek a látszólag világosan elkülönülő szintek összemosódnak, az állam domináns jelenléte és a fogalmi tisztázatlanság azt eredményezi, hogy nem mindig egyértelmü, hogy a miniszter ágazatirányító vagy fenntartói jogkörben jár-e el, a tankerületek és a KK elnökének köznevelési intézmények közalkalmazottaira vonatkozó munkáltatói jogkörökkel kapcsolatos hatásköre pedig a fenntartó és az intézmény közötti határt mossa össze.

Nem véletlen, hogy a jogi szakirodalom is valamennyi fenti elemet magába foglaló, rendkívül általános megközelítéssel kísérelte meg a tanügyigazgatás definícióját, tömören úgy fogalmazva, hogy az a közoktatás szervezése és irányítása (Váradi 2009), illetve részletezőbben kimondva, hogy az az Alaptörvényben meghatározott alapjog biztosításához szükséges, közneveléssel összefüggő szakigazgatási (szervezési, irányítási és ellenőrzési) tevékenységek állam által rendszerbe szervezett összessége (Kozák 2018; Barta-Veszprémi 2015). Az Eurydice által közzétett, a magyarországi helyi és intézményi szintű tanügyigazgatást és oktatásirányítást tárgyaló összefoglaló a KK és a dekoncentrált tankerületi központok intézményfenntartói feladatait emeli ki. Szabó (2000) megközelítésében a tanügyigazgatás a nevelési-oktatási intézmények rendszerszintủ és mindennapi problémáinak kezelését is felöleli az óvodai ellátástól és tankötelezettségtől a pedagógiai munka feltételein, megszervezésén és ellenőrzésén át az egyes intézmények adminisztrativ, pénzügyi és szakmai müködtetéséig, amely sok esetben már kifejezetten intézményen belüli tevékenységeket jelent. Bosch (2010) ennél is tágabban értelmezi a tanügyigazgatást, kimondva, hogy „[a] nevelési-oktatási intézmények a tanügyigazgatás legfontosabb szervezetei", és így nála a tanügyigazgatás magában foglalja az intézmény szintjén a müködéssel összefüggő alapdokumentum-készítési tevékenységet, a gyermeki, tanulói ügyek intézését, valamint a tanügyi dokumentumok, nyilvántartások kezelését és vezetését (Bosch 2010: 9). Ehhez kapcsolódik, amit Kozák (2010) könyvének fülszövegében olvashatunk, miszerint a tanügyigazgatáshoz a fenntartótól az intézményvezetésen át a pedagógusig minden szereplő kötődik. Ugyan a nem jogi szakirodalomban nem találunk összefoglaló meghatározást a tanügyigazgatásra, azonban az azt tárgyaló művek elemzési szempont-, illetve keretrendszeréből kirajzolódik egy, a tanügyigazgatást szélesebb körben értelmező felfogás (vö. Nagy 1994, 1995; Fülöp 2012), és végső soron erre a konklúzióra lehet jutni Fenyö (2014) tanulmánya nyomán is.

Összegezve a fentieket azt mondhatjuk, hogy nincs jogszabályban rögzített tanügyigazgatási fogalom, de részben az egyes normaszövegek alapján, részben a szakirodalomra támaszkodva három típusát különíthetjük elः a tanügyigazgatás szük értelemben az ágazatirányító tevékenységet jelenti, tágabb értelemben már az - elsősorban állami fenntartói tevékenységet is felöleli, legtágabb értelemben pedig minden, a közneveléssel 
kapcsolatos, az intézményen belül is megjelenő tevékenységre kiterjed. A következőkben a szúkebb és tágabb értelemben vett tanügyigazgatás jogi kereteit tekintjük át.

\section{A tanügyigazgatás megvalósulása}

\section{Kizárólagos állami szerepek a tanügyigazgatásban}

$\mathrm{A} z$ Alaptörvény 15. cikke alapján a kormány a végrehajtó hatalom általános szerveként minden olyan feladatot ellát, amelyet az Alaptörvény vagy jogszabály kifejezetten nem utal más szerv feladat- és hatáskörébe; ennek keretében egyben a közigazgatás legföbb szerve, és mint ilyen egyrészt államigazgatási szerveket hozhat létre, másrészt törvényben nem szabályozott tárgykörben, illetve törvényben kapott felhatalmazás alapján rendeletet alkothat. Ezt a köznevelésre mint ágazatra vetítve - egyben figyelembe véve a köznevelést jelenleg átfogóan szabályozó törvény [a nemzeti köznevelésről szóló 2011. évi CXC. törvény (a továbbiakban: Nkt.)] rendelkezését [Nkt. 77. § (1) bek.] - megállapíthatjuk, hogy az oktatásért felelős miniszter ${ }^{3}$ látja el a köznevelés ágazati irányítását, amely általános jellegü, azaz - egyetlen kivétellel (l. szakképzés, amelyet a szakképzésért és felnőttképzésért felelős miniszter ${ }^{4}$ részben önállóan, részben az oktatásért felelős miniszterrel együttesen gyakorol) - kiterjed valamennyi, az Nkt. hatálya alá tartozó tevékenységre, függetlenül a tevékenységet ellátó intézmény vagy szervezet jellegétől, valamint tekintet nélkül azok fenntartójára. Az ágazatirányítás tehát komplex kormányzati feladat, amelyet az állam kizárólagosan gyakorol. Szüdi (2012) még ennél is általánosabban értelmezi az ágazatirányítást, utalva az Országgyülés kiemelt szerepére a törvényi keretek megalkotásával. Egyszerre van jelen benne átfogó, stratégiai jellegű feladat, mint például általában az oktatáspolitika, ideértve a köznevelés fejlesztését, az óvodai nevelés országos alapprogramjával és a nemzeti alaptantervvel kapcsolatos feladatokat, valamint az ágazati szabályozás előkészítését és ellátását, de egyes napi szintű müködés irányításával összefüggő tevékenységeket is, így a különféle jóváhagyási jogkörök gyakorlását is magában foglaló ellenőrzést, az intézményhálózat müködtetését, illetve ehhez kapcsolódóan az intézmények létrehozásával és megszüntetésével kapcsolatos feladatokat is, továbbá a formanyomtatványok jóváhagyását, a tankönyvkiadással, -forgalmazással és -támogatással kapcsolatos, valamint az információs rendszerekkel, illetve a statisztikai adatszolgáltatással összefüggő hatásköröket is. Ráadásul mindezek csak a legfontosabb, az Nkt.-ban rögzített hatáskörök, számos más jogszabály is utalhat ágazatirányító jellegü feladatot a szakminiszter hatáskörébe (Szz̈̈di 2012).

A minisztereket különféle hivatalok segítik hatáskörük gyakorlásában: az oktatásért felelős minisztert az $\mathrm{OH}$, amely ellátja az állami intézmények nyilvántartását, müködésük engedélyezését, a konkrét ellenőrzést. A szakképzés tekintetében ettől eltérő típusú, leginkább a képzés technikai hátterét és feltételeit (pl. az országos modultérkép összeállítása és nyilvánosságra hozása, a nemzeti referencia és koordináló központ, valamint a szakképzési tájékoztatási és információs központ müködtetése, a szakképzési hozzájárulással, valamint a szakképzési és felnőttképzési támogatásokkal kapcsolatos különböző hatáskörök gyakorlása, a szakképzési centrumok pedagógiai-szakmai tevé-

Jelenleg az emberi erőforrások minisztere.

Jelenleg az innovációért és technológiáért felelős miniszter. 
kenységének, illetve a regisztrációs és tanulmányi alaprendszer müködtetése, kutató és fejlesztő-szolgáltató feladatok ellátása) biztosító feladatai vannak az állami szakképzési és felnőttképzési szervként kijelölt Nemzeti Szakképzési és Felnőttképzési Hivatalnak. E szakigazgatási szervek mellett mindkét esetben általánosságban hatáskörrel bírnak a Fővárosi és a Megyei Kormányhivatalok, amelyek a köznevelési feladatokat ellátó hatóságként járnak el - szakképzési feladatot ellátó hatóságként kizárólag a Pest Megyei Kormányhivatal jár el. A kormányhivatal a miniszter köznevelési feladatainak megszervezéséhez szükséges döntései előkészítésében és végrehajtásában müködik közre, valamint a nem állami költségvetési szerv vagy települési önkormányzat által alapított és fenntartott intézmények nyilvántartását, mủködésük engedélyezését végzi, illetve ellátja konkrét ellenőrzésüket, emellett elbírálja a tanulók felvétellel, átvétellel, érettségivel kapcsolatban előterjesztett jogorvoslati kérelmeit.

A fentiekből látható, hogy az ágazatirányítás a köznevelés területén is bonyolult szervezetrendszerben valósul meg, de hasonlóan „többszereplős” a szakképzés vonatkozásában is. Ami viszont külön megnehezíti a tanügyigazgatás ezen szintjének áttekintését, hogy az egyes feladatok és hatáskörök nem párhuzamosan jelennek meg, hanem a kormányhivatal és a szakigazgatási szerv hatásköreibe tartozó konkrét feladatok eltérőek attól függően, hogy köznevelésről vagy szakképzésről van szó.

\section{A tanügyigazgatás megjelenése a fenntartói irányításban}

$\mathrm{A} z$ Alaptörvény nem csupán áttételesen - a kormány hatáskörén keresztül - érinti a köznevelés kérdéskörét. Egyrészt a tanítással összefüggő alapjogot deklarálja, másrészt garantálja a művelődéshez való jogot. A X. cikk szerint Magyarország törvényben meghatározott keretek között biztosítja a tanítás és a tanulás szabadságát egyaránt. Ehhez szorosan kapcsolódik a XI. cikk, amely szerint minden magyar állampolgárnak joga van a művelödéshez, amely alapjogot Magyarország a közművelődés kiterjesztésével és általánossá tételével, az ingyenes és kötelező alapfokú, az ingyenes és mindenki számára hozzáférhető középfokú oktatással, továbbá az oktatásban részesülők törvényben meghatározottak szerinti anyagi támogatásával biztosít. Az Alaptörvény fenti rendelkezéseiből több következtetést vonhatunk le: egyrészt a törvény csak a tanítás szabadságának szabhat kereteket, de a tanulás szabadsága korlátlan. Másrészt ezeket az alapjogokat általánosságban Magyarország biztosítja, ami azt jelenti, hogy azok érvényesítése nem csupán az államnak, de minden magyar állampolgárnak és magyar szervezetnek kötelessége. Az Alaptörvény azt sem jelöli meg pontosan, kinek a feladata az ingyenes és kötelező alapfokú, ingyenes és mindenki számára hozzáférhető középfokú nevelés-oktatás biztosítása. Ugyan az ágazatirányítási hatáskörből indirekt módon már lehet erre következtetni, de az Nkt, explicit módon is deklarálja, hogy az állam gondoskodik a köznevelési alapfeladatok ellátásáról, ${ }^{5}$ méghozzá az érettségi megszerzéséig, illetve a szakképzésről szóló törvényben meghatározott feltételek szerinti második szakképesítés megszerzését biztosító első szakmai vizsga befejezéséig. Az Nkt. a köznevelési alapfeladatokat a köznevelés közfeladataiként azonosítja. Az állam tehát közfeladatot biztosít. Az óvodai nevelés kiemelése ebből a körből azért is meglepő, mert az Alaptörvény a helyi önkormányza-

Ez alól csak az óvodai nevelés, a nemzetiséghez tartozók óvodai nevelése, a többi gyermekkel együtt nevelhető, sajátos nevelési igényü gyermekek óvodai nevelése jelent kivételt. 
tokat az államra vonatkozó részben szabályozza, és a szakirodalom - alkotmányjogi és közigazgatási jogi megközelítésből egyaránt - egyértelműen az államszervezet részeként azonosítja őket (Árva 2013). A köznevelési közfeladat államhoz pozícionálásából az is következik, hogy a köznevelési intézmények alapítására és fenntartására is az állam rendelkezik elsősorban jogosultsággal. Ugyanakkor nem sokkal később azt az Nkt. is egyértelművé teszi, hogy az állam "gondoskodási” kötelezettsége nem csupán konkrét intézményfenntartói feladatokkal valósulhat meg, de annak oly módon is eleget tehet, hogy azt egyházi, illetve nemzetiségi önkormányzat fenntartásában álló vagy a magán köznevelési intézmény útján látja el. Az ágazatirányítással szemben a fenntartói feladatok tehát nem kizárólagos állami monopóliumot jelentenek. Maga a „fenntartó” fogalom az Nkt.-ban definiált: olyan természetes vagy jogi személyt jelent, aki vagy amely a köznevelési feladat ellátására való jogosultságot megszerezte vagy azzal rendelkezik, és a köznevelési intézmény müködéséhez szükséges feltételekről gondoskodik. Ebből tudjuk az intézményfenntartás fogalmát is levezetni, ami lényegében nem más, mint a müködéshez szükséges feltételekről való gondoskodás. Ilyen feladatokat az állam mellett a már említett szervezetek (nemzetiségi önkormányzat, egyházi jogi személy, vallási tevékenységet végző szervezet, egyéb magánfenntartók) is elláthatnak. Óvodát települési önkormányzat is alapíthat és fenntarthat, valamint bármilyen köznevelési intézmény esetében lehet fenntartó felsőoktatási intézmény is.

Mindebből következően az intézményfenntartási (működtetési) kötelezettség önmagában nem minősül tanügyigazgatásnak, az állam ezzel kapcsolatos általános hatáskörei az ágazatirányítás keretében valósulnak meg. Az előzőekben azonban láthattuk, hogy a konkrét fenntartói feladatokat a szakirodalom már tanügyigazgatásként értelmezi, miközben abban az Nkt. hatályba lépése sem hozott változást, hogy a fenntartói jogosítványok egységesek a fenntartó személyétől függetlenül (Szüdi 1997). Ugyanakkor az állam fenntartói feladatai minőségüket tekintve eltérnek a többi fenntartóétól. Szüdi (1997) szerint a fenntartói irányítás kulcseleme a feladatellátás megszervezése, amely átfogja a létesítést, a tevékenység megszervezését, a költségvetés meghatározását, a belső szabályozást, a vezető(!) feletti munkáltatói jogok gyakorlását és az ellenőrzést, jóváhagyási jogköröket, mindezeket világos törvényi keretek között. Az egyéb fenntartók esetében ez másfél évtizeddel később sem változott (Szü̈di 2012), ám míg azok esetében egy egymástól elkülönülő szervezetek közötti kapcsolatot látunk, az állam egyes fenntartói feladatai - elsősorban egy úgynevezett középirányító szerv, a KK mint központi hivatal bekapcsolása révén - sokkal inkább, illetőleg tisztán igazgatási jellegű tevékenységként valósulnak meg. Ugyan a fenntartói feladatokat a tankerületi központok látják el, de a KK irányítása alatt. A KK az állam fenntartói jogait gyakorolja, szervezi és ellenőrzi a tankerületi központok müködését, kiemelten azok költségvetési és vagyongazdálkodását. Ezenkívül közremüködik a munkáltatói jogkörök gyakorlásában. A hatályos szabályozás szerint tehát a KK és a tankerületi központok között megoszlanak a hatáskörök. Ez a megoldás tehát enyhített azon a központosításon, amely a Klebelsberg Intézményfenntartó Központ (KLIK) megalapításával valósult meg, de nyilvánvalóan még mindig sokkal közelebb áll a centralizált működéshez, mint amikor a helyi közügyek intézése és a helyi közhatalom gyakorlása érdekében müködő helyi önkormányzatok gyakorolták a fenntartói jogokat (vö. Szabó 2000). 


\section{Intézményvezetés és tanügyigazgatás}

Az állami és egyéb fenntartású intézmények irányítása közötti különbség leginkább az intézményvezető jogkörén keresztül válik nyilvánvalóvá. Elvben meghúzható egy világos határ a köznevelési intézmény és fenntartója között (Szüdi 2012), amely az intézmény müködésébe csak annak vezetőjén keresztül avatkozhat be. A vezető teljes jogkörrel és felelősséggel jár el, ez utóbbinak része az is, hogy munkatársait megválogassa. Az állami fenntartó és intézményei közötti világos határvonal azonban elmosódik, a fenntartó képes közvetlenül is beavatkozni az intézmény müködésébe, amely egyúttal a tanügyigazgatás egy sajátos megjelenését is eredményezi. Ezáltal ugyanis a tanügyigazgatási tevékenység tovább bővül és bizonyos, korábbi, illetve a nem állami intézmények esetében jelenleg is vezetői hatáskörök igazgatási-irányítási hatáskörré alakulnak át. Ez még akkor is így van, ha mindez jelenleg kevésbé egyértelmüen jelenik meg, mint a KLIK megalapításakor, amikor az Nkt. a köznevelési intézmény alkalmazottai feletti, a bérgazdálkodást érintő, a kinevezésre és a közalkalmazotti jogviszony megszüntetésére vonatkozó munkáltatói jogköröket a KLIK vezetőjéhez, azaz a szervezeten kívülre telepítette, s ezzel a KLIK elnökét az ország legtöbb munkavállalója felett munkáltatói jogkört gyakorló vezetőjévé tette, amely ráadásul komoly zavarokhoz vezetett (Asztalosné 2017). Ennek legfőbb oka az irreálisan nagy létszám volt, amelynek kezelése lassú volt, és gyakran formális döntéseket eredményezett. A kormány ezért a centralizáció enyhítése mellett döntött átalakítva a KLIK-et és megalapítva a tankerületi központokat. Ez a változás azonban nem oldotta meg azt a problémát, hogy az intézményvezető jogköre korlátozott, és - leginkább a munkáltatói jogkör révén - a tankerület fenntartóként továbbra is beavatkozhat a napi müködésbe, ezáltal konzerválva az elmosódott határokat és a tanügyigazgatás klasszikus értelmezésen való túlterjeszkedését. A köznevelési intézmény vezetője ugyanis továbbra sem kapta vissza munkáltatói jogkörét a korábban a KLIK elnökéhez telepített intézkedések tekintetében, továbbra sem rendelkezik szabadon a saját munkatársai jogviszonya felett: a köznevelési intézmény vezetője csupán javaslatot tehet a pedagógus és nevelöoktató munkát közvetlenül segítő munkakörben dolgozó alkalmazott kinevezésére és felmentésére, mindez csak a tankerületi központ vezetőjének egyetértésével valósulhat meg. Egyetértés hiányában a KK vezetője dönt. Ez azért is az általános munkajogi szabályozástól és gyakorlattól eltérő megoldás, mert a tankerületi központ vezetője a KK elnöke munkáltatói és egyben utasítási jogköre alá tartozik, amivel lehetővé válik, hogy felülről avatkozzanak be egy intézmény müködésébe, az egyetértési jog megtagadására utasítással a KK szintjére emelve egy adott munkáltatói intézkedés meghozatalát (Rónay 2018). Még inkább szembetűnő az intézményvezető korlátozott jogköre, amikor a köznevelési intézmény pedagógusa vagy a nevelö-oktató munkát közvetlenül segítő alkalmazottja rendkívüli felmentésére okot adó körülmény merül fel (a közalkalmazotti jogviszonyból eredö lényeges kötelezettségét szándékosan vagy súlyos gondatlansággal jelentős mértékben megszegi, vagy olyan magatartást tanúsít, amely a közalkalmazotti jogviszony fenntartását lehetetlenné teszi), ilyenkor a jogviszony megszüntetésére a köznevelési intézmény vezetőjének egyetértése nélkül kerül sor.

A kialakított megoldás teljes mértékben szemben áll a szubszidiaritás elvével, amely azt biztosítja, hogy a munkáltatói jogok gyakorlójának pontos ismerete legyen a vezetett egység tevékenységéről, illetve a beosztottak munkavégzéséről (Kiss 2000; Gyula- 
vári 2016). A vezetővel szemben alapvető elvárás a vezetett szervezet és ezáltal annak beosztott munkatársai tevékenységéért való felelősség, amely csak akkor lehet teljes, ha az adott vezetőnek érdemi ráhatása van a beosztott személyi körre. A legalapvetőbb munkáltatói jogok nélkül felelős vezetés sem várható el.

\section{Speciális tanügyigazgatási feladatok}

A köznevelésre vonatkozó jogszabályegyüttes számos olyan részfeladatot szabályoz, amely vagy amelynek egyes elemei tanügyigazgatási feladatként határozhatók meg. Noha ezen tevékenységek az intézményeknek vagy azok alkalmazottainak akár napi szintű működését érintik, az állam - elsősorban ellenőrző funkciói révén - azokba bekapcsolódik. Ezen esetekben az állami (kormányzati) megjelenés túlmutat az ágazatirányítás szabályozó és stratégiai szerepkörén, és aktív igazgatási beavatkozások formájában valósul meg.

A tanügyigazgatás legtágabb értelemben vett megközelítése is az intézményben megjelenő tevékenységeket az intézmény keretein belül, a vezetői hatáskörrel lefedetten értelmezi, ezért látványosak azok az elemek, amelyek az ilyen típusú ügyekben is az állami közigazgatási jellegű szerepvállalást alapozzák meg. A tanügyigazgatási tevékenység ilyen típusú megjelenése a pedagógusok előmeneteli rendszerében a leginkább szembetűnő. Ennek részletes szabályait a pedagógusok előmeneteli rendszeréről és a közalkalmazottak jogállásáról szóló 1992. évi XXXIII. törvény köznevelési intézményekben történő végrehajtásáról szóló 326/2013. (VIII. 30.) Korm. rendelet (a továbbiakban: Nkt. Vhr.) rögzíti. Ennek keretében az életpálya szakaszain való haladáshoz szükséges minősítő vizsga és ellenőrzések eljárásrendjét szabályozza igazgatási-igazgatásszervezési megközelítésben. Itt a tanügyigazgatás nem csupán a pedagógusi müködés értékelése és egyfajta minőségbiztosítás érvényre juttatása, hanem olyan konstrukció, amelyben a minősítő vizsga sikeressége a magasabb (fizetési) fokozatba sorolás feltétele, sikertelensége vagy elmulasztása pedig munkajogi típusú szankciót von maga után, amely akár a jogviszony megszünése is lehet. A minősítő vizsga Nkt. Vhr. által megállapított eljárásrendje egyértelműen igazgatási jellegü, amit az is kifejez, hogy nem csupán a technikai jellegü közreműködés, de lényegében az érdemi folyamat is az $\mathrm{OH}$ által valósul meg (Nkt. Vhr. 4.-4/A. cím). Ennek leginkább látványos eleme az, hogy az értékelés során a szakmai véleménykülönbségek alapján az eredményt a pedagógus nem vitathatja [Nkt. Vhr. 12/D. § (4) bek.].

\section{Konklúziók}

Amikor a tanügyigazgatást vizsgáljuk, szembesülnünk kell a fogalmi tisztázatlansággal. Látszólag ugyan egy mindenki számára érthető jelentéssel bíró kifejezésről van szó, de a róla való gondolkodás során többen eltérően közelítik meg, értelmezik. Nem csupán az oktatás területével foglalkozó nem jogtudományi természetű kutatásokban figyelhető meg az értelmezés többfélesége, de maga a jogirodalom sem egységes akkor, amikor részletes definíciót kíván adni. Természetesen az általános meghatározás mint legkisebb közös többszörös ugyanoda konkludál, de éppen ezért nem jelent valódi támpontot. A jogirodalmi megközelítések sokszínüségéhez pedig maga a joganyag vezet el. A jogalkotó hajlamos gyakran kézenfekvő fogalmakhoz is értelmező rendelkezést füzni, azon- 
ban a tanügyigazgatás esetén elmarad mindez. A jogszabályok szisztematikus elemzése azt mutatja, hogy maga a jogalkotó is magától értetődően használja a tanügyigazgatást, és ezért e kifejezés jobbára technikai jellegü rendelkezésekben fordul elő. Ugyanakkor korántsem feltétlenül csak technikai jellegű normákban, sokszor a magasabb szintű jogszabályokban is. Sőt - amennyiben elfogadjuk e kifejezéssel leírt tevékenységek tartalmát és körét - nem ritkán találhatunk olyan rendelkezéseket is, amelyek ugyan nem definiáltak explicit tanügyigazgatási tevékenységként, mégis egyértelműen ekként azonosíthatók. Mindezek alapján elfogadhatjuk a legáltalánosabb fogalommeghatározást, miszerint valamennyi, a közneveléshez (nevelési-oktatási tevékenységhez) kapcsolódó irányítási, szervezési és ellenőrzési tevékenység tanügyigazgatásnak minősül. Ez azt is jelenti - és a jogszabályok logikája is ugyanez -, hogy a tanügyigazgatás a tisztán és kizárólagosan kormányzati hatáskörtől a fenntartó ez irányú feladatellátásán át egészen az iskolában megvalósuló vezetői munkavégzésig - sőt egyes nézetek szerint egészen az osztályterem falain belül, a pedagógus és tanuló közötti interakciók bizonyos típusait is felölelő átfogó tevékenység (Bosch 2010). Ez vezet el a tanügyigazgatás szükebb, tágabb és legtágabb értelemben vett fogalmához, amit jogi-igazgatási szempontból az ágazatirányítás, a fenntartói irányítás és az intézményvezetés fogalmával azonosíthatunk. Ugyanakkor mindebből következően a tanügyigazgatás a legkülönfélébb területeken is megjelenik - nem csupán a szorosan értelmezett igazgatás-irányítási-vezetési spektrumban. Azaz nem kizárólag a működtetéssel, ellenőrzéssel, szabályozással, jóváhagyással kifejezetten összefüggő hatáskörökben jelenik meg a tanügyigazgatás, de olyan - látszólag (?) - tisztábban szakmai kérdésekben, mint akár a pedagógusok előmenetele vagy akár a továbbképzés kérdésköre.

A hazai jogszabályi környezetet áttanulmányozva két sajátos jelenséget figyelhetünk meg. Egyrészt az igazgatási szempontú megközelítést, azaz számos szakmai kérdés igazgatási irányból való rendezését, igazgatási tevékenységként felfogását és ekként való szabályozását. A legtisztábban ez a pedagógus-előmeneteli és -minősítési rendszerben érhető tetten, amelyben a folyamatos szakmai fejlődés, a pedagógusok tanulási folyamata igazgatási-ellenőrzési szempontból szabályozott és ekként értelmezett, lényegében egy hatósági típusú folyamatként került megkonstruálásra. A másik sajátosság az állam domináns jelenléte a legalacsonyabb szintủ és a leginkább szakmai típusú folyamatokban is. Ez az elemzés nem adott lehetőséget annak megválaszolására, hogy e dominancia a rutinszerü igazgatási típusú szabályozás eredménye, vagy a tanügyigazgatás széles körü értelmezése és erős jelenléte az állam hangsúlyos részvétele iránti igény következménye-e. A z viszont egyértelmü, hogy a fenntartói irányítás tanügyigazgatási feladatként értelmezése azzal kiegészülve, hogy az intézményfenntartás - noha nem állami monopólium -, de elsődlegesen állami feladat, amely számosságát tekintve is túlnyomó részben van jelen, azt is jelenti, hogy az ágazatirányítás és a fenntartás közötti határvonal elmosódik és lehetőséget ad a különböző funkciók összekeveredésére. Ezt tovább bonyolítja az a sajátos megoldás, amely elveszi a munkáltatói jogot az állami fenntartású intézmények vezetőjétől és egyetértési joga folytán (illetve kivételes esetben kizárólagosan) a regionális fenntartói funkciót betöltő tankerületi igazgatóhoz, közvetve - az egyetértési jog megatagadás esetén biztosított végső döntési jogköre folytán - a Klebelsberg Központ elnökéhez telepíti azt. Ez összhangban áll azzal a kormányzati ideával, amely szerint „[a]z új köznevelési rendszerben a menedzser típusú intézményvezető helyett egyfajta pedagógiai-szakmai vezetőre van szükség, hiszen a menedzsmentfeladatok nagy része 
az állami intézményfenntartóhoz került" (Köznevelés-fejlesztési stratégia 2014: 59). Ez viszont azt is eredményezi, hogy a fenntartó és a fenntartott intézmény közötti határok is elmosódnak, az új típusú „egyfajta pedagógiai-szakmai vezető” már nem közvetítő az intézmény és a fenntartó között, hanem a szakmai feladatok koordinálója, miközben a menedzsmentfeladatok már a fenntartónál kapnak helyet. Ezáltal a fenntartói típusú tanügyigazgatási tevékenység is más értelmet nyer, hiszen kormányzati aktivitásként jelenik meg az intézmény falai között.

Mindez pedig új megvilágításba helyezi az Alaptörvénynek a tanítás szabadságáról szóló deklarációjában elhelyezett diszkrét korlátozást, miszerint az a törvényben meghatározott keretek között biztosított. A törvény - jelesül az Nkt. - teremti meg ugyanis a tanügyigazgatás nem csupán tág, de az egyes fogalmi megközelítések közötti különbségeket összemosó értelmezését, és teszi lehetővé, hogy a tanügyigazgatás legalábbis egyes elemei révén akár a tanítás szabadságának korlátozójaként is funkcionálhasson. Elegendő csak a tankönyvkiadás és tankönyvforgalmazás ellenőrzésére vonatkozó miniszteri hatáskörre vagy a pedagógiai program jóváhagyását magában foglaló fenntartói jogosítványokra gondolni. Ebből a szemszögből pedig egészen másként látszik a tanügyigazgatás fogalmának jogszabályi meghatározatlansága: az ebből adódó képlékeny értelmezés számos további lehetőséget rejt magában, elsősorban a kormányzat számára biztosítva, hogy a mindenkori törvényalkotói (egyszerü) többség birtokában akár közvetlenül, akár törvényben a kormányt felhatalmazva tovább szükítse az oktatással összefüggő szabadságokat.

\section{IRODALOM}

Asztalosné Zupcsán E. (2017) Változás vagy változtatás. Adalék a Klebelsberg Intézményfenntartó Központ (KLIK) átalakításáról. Új Magyar Közigazgatás, Vol. 10. No. 2. pp. 22-28.

Árva Zs. (2013) Kommentár Magyarország Alaptörvényéhez. Budapest, Wolters Kluwer.

Barta A. \& Veszprémi B. (2015) Tanügyigazgatási és közigazgatási ismeretek. Debrecen, Debreceni Egyetemi Kiadó.

Bosánszky L. (1986) Az igazgatás, irányítás, vezetés, felügyelet, ellenőrzés, vizsgálat fogalmakról. Állam és Igazgatás, Vol. 36. No. 6. pp. 503-515.

Bosch M. (2010) Tanügyigazgatás és munkajog. Budapest, Alfa Rehabilitációs Kht.

Csapó J. (1998) A kerületi tanügyi igazgatás kihívásai. Magyar Közigazgatás, Vol. 48. No. 1. pp. 56-62.

Eurydice - Magyarország: Helyi és intézményi szintủ tanügyigazgatás és oktatásirányítás. https://eacea.ec.europa.eu/national-policies/eurydice/magyarorsz\%C3\%A1g/ administration-and-governance-local-andor-institutional-level_hu [Letöltve: 2019. 04. 18.]

Fazekas M. (2017, ed.) Közigazgatási jog. Általános rész III. Budapest, ELTE Eötvös Kiadó.

Fayol, H. (1920) Administration Industrielle et Générale. Paris, Dunot.

Fenyő D. Gy. (2014) Tanügyigazgatás vagy osztályterem. Új Pedagógiai Szemle, No. 1-2. pp. 89-98. http://folyoiratok.ofi.hu/uj-pedagogiai-szemle/tanugyigazgatas-vagyosztalyterem [Letöltve: 2019. 04. 17.] 
FüLöp Gy. (2012) A magyar tanügy-igazgatási jog létrehozása és szakigazgatási szervezetrendszerének kialakítása a dualizmus korában. In: Stripta I. (ed.) Studia iurisprudentiae doctorandorum Miskolciensium. Miskolci doktoranduszok jogtudományi tanulmányai. Miskolc, Gazdász-Elasztik. Tomus 11. pp. 59-80.

Gyulavári T. (2016, ed.) Munkajog. Budapest, ELTE Eötvös Kiadó.

KIss Gy. (2000) Az új Ptk. és a munkajogi szabályozás, különös tekintettel az egyéni munkaszerződésekre. Polgári Jogi Kodifikáció II/1. pp. 3-17. http://ptk2012.hu/wp-content/ uploads/2012/11/2000-1PJK.pdf [Letöltve: 2019. 04. 25.]

KоzÁк A. (2010) Fontosabb változások a tanügyi és a közoktatást érintő munkajogi szabályozás terén. Budapest, L'Harmattan.

KоzÁк A. (2018) A tanügyigazgatás szervezeti és funkcionális rendje. http://www.fupi.hu/ dokumentumok/2017/a_tanugyigazgatas_szervezeti_es_funkcionalis_rendje.pdf [Letöltve: 2019. 04. 17.]

Köznevelés-fejlesztési stratégia (2014) https://www.kormany.hu/download/6/fe/20000/ K\%C3\%B6znevel\%C3\%A9s-fejleszt\%C3\%A9s.pdf [Letöltve: 2019. 05. 11.]

Nagy P. T. (1994) Tanügyigazgatás és oktatáspolitika a polgári Magyarországon. Kandidátusi disszertáció. http://real-d.mtak.hu/814/1/11756.pdf [Letöltve: 2019. 04. 18.]

Nagy P. T. (1995) Az 1941-es tanügyigazgatási törvény. Magyar Pedagógia, Vol. 95. No. 1-2.pp. 59-76.

RónAY Z. (2018) Jogszerüség és etika a tanári pályán. Budapest, ELTE Eötvös Kiadó.

Szabó L. (2000) Tanügyigazgatási problématár. Válogatás a közoktatási intézmények tanügyigazgatási gyakorlatából. Budapest, Okker.

Szüdi J. (1997) A fenntartói irányítás. In: Palotás Z. (ed.) Önkormányzat és közoktatás '97 Szekszárd, 1997. április 17-18. Szekszárd, Tolna Megyei Önkormányzat Pedagógiai Intézete. pp. 25-31.

SzüDI J. (2012) Kommentár a köznevelési törvénybez. Budapest, CompLex.

VÁradi L. (2009) A müvelödésigazgatás kézikönyve. Budapest, HVG-ORAC.

A cikk a Creative Commons Attribution 4.0 International License (https://creativecommons.org/licenses/ by/4.0/) feltételei szerint publikált Open Access közlemény, melynek szellemében a cikk bármilyen médiumban szabadon felhasználható, megosztható és újraközölhető, feltéve, hogy az eredeti szerző és a közlés helye, illetve a CC License linkje és az esetlegesen végrehajtott módosítások feltüntetésre kerülnek. (SID_1) 